\title{
The Representation of Sexuality in Putri Jaleka Manuscript
}

\author{
Niken Putri Andana Kusuma ${ }^{1}$, Turita Indah Setyani ${ }^{2}$ \\ \{niken.putri71@ui.ac.id ${ }^{1}$, turita.indah@ui.ac.id ${ }^{2}$ \} \\ ${ }^{1,2}$ Universitas Indonesia, Depok, Indonesia
}

\begin{abstract}
Putri Jaleka (PJ), beside Sĕrat Centhini, Sěrat Nitimani, Sěrat Gatholoco is one of the Javanese manuscripts which discusses sexuality. This paper examines sexuality aspect in PJ manuscript. PJ is written in the form of tembang macapat in which canto of the tembang constitutes certain characteristics related to its content. This mode of writing affects the function of tembang to convey the sexuality depiction. Therefore, this article is aimed at describing the representation of sexuality in PJ by referring to the meaning of the sembah catur (four worship) concept in Javanese culture by Roland Barthes' semiotics. The theory allows this paper to read the sexual depiction in PJ as signifier and their relations with sembah catur as the signified concept. The results show that the representation of sexuality in $\mathrm{PJ}$ in the form of mijil cantos conveys the beginning of Jaleka's sexual intercourse with Yusup. At the same time, mijil can also be understood as the beginning of her spiritual journey towards perfection. This study concludes that the depiction of sexual activity in PJ represents Javanese view on sexuality, that is as a spiritual means to achieve the union with God through the manifestation of sembah catur (raga, cipta, jiwa, rasa).
\end{abstract}

Keywords: mijil, Putri Jaleka manuscript, representation of sexuality, sembah catur,

\section{INTRODUCTION}

Tembang macapat is one form of traditional poem used by the Javanese as a teaching medium in their daily lives [1]. The terms used for macapat is related to the religious teaching on the Javanese conception on human life [2]. Tembang in Javanese means a flower bouquet. Wali (Javanese Islamic saints) proposed to deliver Islamic teachings in a beautiful, fun, and exciting, like sprinkling flower petals. Islamic teachings should not be delivered in a harsh manner, for example by the use of curse or chaff that may hurt the listeners' feelings [3]. Meanwhile, the terms used for macapat name describe the stages of human life: (a) mijil (birth), (b) sinom (young age), (c) maskumambang (adventurous), (d) asmaradana (romantic life), (e) dhandhanggula (living in happiness), (f) durma (taking a step back from world's luxury), (g) pangkur (absent from worldly ambition), (g) gambuh (full understanding of life), 
(h) pocung (death, wrapped in shroud), (i) megatruh (the separation of soul with the body), and (j) kinanthi (human deeds brought for afterlife judgment) [3].

Putri Jaleka (PJ) is one of Javanese manuscripts written in macapat form. It is an old Banyumas (Central Java) manuscript archived at the University of Indonesia Library written in Javanese script and Javanese language. It composed of four cantos: dhandhanggula (53 verses), kinanthi (20 verses), mijil (105 verses), and sinom (5 verses). According to the literature review on previous research, PJ manuscript is not yet studied by other scholars.

Sexual depiction in PJ is similar with the other related Javanese manuscripts such as Serrat Nitimani, Sĕrat Centhini, Sěrat Darmogandhul, and Sěrat Gatholoco. Compared to the other texts, PJ depicted the sexuality in mijil cantos. Each canto has its own characteristic in relation to its content and point of view in representing sexuality. Therefore, the meaning embedded in each canto is different from one to another. There have been several studies on the characters in Serrat Centhini [5] and the use of metaphor in the particular text [6]. In addition, Serrat Gatholoco described the dialogues between Gatholoco and Dewi Perjiwati on the essential nature of male and female, asmaragama behaviours, and the beginning of human life. Previous studies on Serrat Gatholoco affirmed the explanation about human bodies in text and critics toward ascetism [7]; and also examined the analogical relationship between sexuality and the concept of manunggaling kawula gusti [4]. The analogy can also be found in Sĕrat Darmogandhul [4].

The representations of sexuality in the other manuscripts have been analysed to be related with the concept of human union with God. However, the depictions of sexuality in the other texts are represented in the construction of characters and the Javanese ethics and morality despite the concept of sembah catur. At the same time, this concept in Javanese philosophy has not yet studied. Therefore, this article is aimed at revealing the meaning of sexual depiction in PJ by referring to the concept of sembah catur or 'four worship' in the Javanese philosophy.

\section{METHOD}

This article combines qualitative research method and semiotics theory by Roland Barthes. The theory allows this paper to read the sexual depiction in PJ as signifier and their relations with sembah catur as the signified concept. Semiotics is as a study of sign or system that allows viewing certain entities as signs or as something meaningful [8]. Saussure's view on sign had been developed by Barthes into two levels of meaning. Signs (signifier and signified) is combined in the first step to form signifier, followed by the formation of new signifier during the next step [9].

\section{RESULT AND DISCUSSION}

Sexuality is an important aspect in human existence and basic personality [4]. At the same time, it has become one of the biggest mysteries in human life. Therefore, it should be understood not only as a physical need, but also an emotional and social unity [4]. PJ mentioned two kinds of sexual body parts namely primary and secondary, as well as the sexual activity of Jaleka and Yusuf. Despite the use of explicit words, the depiction of sexual activity in PJ is described in metaphors. Sexual activities are described in 97 verses in the form of mijil. Mijil is used to describe the beginning of Jaleka's sexual intercourse. Mijil canto is the symbol of sexuality manifested in the names of tembang macapat. Mijil kingkin (symbol of an aroused couple), mijil wedharingtyas (symbol of a couple communicating each other's desire), mijil raramanglong (symbol of a couple dedicating themselves to each other) [10]. Therefore, mijil in PJ to describe sexual intercourse as this form symbolizes sexuality in tembang macapat. On the other hand, mijil also contains the depiction of a foreplay which 
includes touching the secondary sexual body parts preceding the primary one. As mijil also used in Javanese literature to describe the birth of a baby or the beginning of a human life [11], it can be referred that mijil form is used in PJ to describe the start of a sexual intercourse.

However, PJ does not only use mijil cantos to narrate a foreplay. It is used to describe the whole process of sexual intercourse in 97 verses. Reference to Javanese view on sexuality helps to understand the meaning of mijil in PJ. Kejawen philosophy on sexuality considers sexual intercourse as a noble activity as it is believed to be the representation of human minds. In other words, the Javanese believes that sexual intercourse is not only a physical contact between male and female, but a spiritual relationship. Javanese concept of sexuality considers intercourse as a means to understand the origin of human being and to reach the life perfection [12].

Kejawen philosophy considers sexual intercourse as a form of amemayu hayuning bawana or efforts to attain the world's harmony. Sexual intercourse is believed as a means to show devotion (sembah sujud) to God [12]. Sembah in Javanese is a form of respect manifested in specific behaviors [13]. Sexual activity is included in sembah behaviour, which according to Serat Wedhatama is composed of sembah raga, sembah cipta, sembah jiwa, and sembah rasa. All of them are united in sexual intercourse [12]. In other words, the Javanese philosophy considers sexual activity to function as a form of sembah sujud towards God. The four kinds of devotion in catur sembah concept is referred to laku (behaviour) orders during an individual's life to understand the essence of his being (pakartine wong amagang laku) [14]. The concept of catur sembah is manifested in mijil cantos of $P J$ manuscript.

\subsection{Sembah Raga}

Human body is a physical entity that should be maintained and taken care of for the sake of material and spiritual health to allow an individual carry out his worldly tasks properly [14]. Sembah raga is the act of showing devotion towards God by emphasizing the physical movements and behaviors [15]. Therefore, sembah raga is a physical sembah conducted by an individual.

Sembah raga in PJ is described at the beginning of Jaleka's intercourse with Yusup in mijil verse 9. The verse contains several signifying words such as 'touched', 'squeezed', 'pulled', and 'sucked'. Those words depicted physical activities and can be understood to relate with the concept of sembah raga. Therefore, the signifier of physical activities during sexual intercourse contained in verse 9 represents the concept of sembah raga with its relation to physical worship.

\subsection{Sembah Cipta}

The literal meaning of cipta is idea, wishful thinking, or hope and desire in human mind. However, sembah cipta refers to sembah hati or heartily worship, instead of idealistic worship [15]. This concept is still related to the idea of physical human body with emphasize on the act of purification without the use of water [14]. Instead, the purification is done by supressing lust [16]. Therefore, sembah cipta is the act of God worshipping with the emphasize on human heart.

This concept is described in mijil verse 16 in PJ by Jaleka's denial to have sexual intercourse with Yusup. According to her, Yusup's abusive tendency is not appropriate, as mentioned in the following words: 'surely', 'if I think about it', and 'break the norm'. Those words are the signifier of Jaleka's attempt to repress her lust and sexual drive and relate to the concept of sembah cipta.

\subsection{Sembah Jiwa}


In conducting spiritual journey according to Javanese philosophy, an individual is expected to understand the substance of mindful teaching through sembah jiwa. Sembah jiwa is a form of devotion towards God by emphasizing the role of human soul. Human's task in the world is to become the God's messenger. Therefore, during their journey in exercising the task, all worldly happenings and feelings such as fortune or accident, happiness and sadness, healthy and sick, should be accepted without complaint [15]. Sembah jiwa is the higher level of devotion which implies non-physical matter. In this phase, human being will be able to understand that life flows in accordance with the universe and the path of spiritual [14].

Sembah jiwa in PJ is represented in the verse 81 by the narration of Jaleka's disappointment of Yusup's sexual behaviour. Her disappointment represents an individual's feeling during his life journey where he deals with the fate written by God. It corresponds with the Javanese concept of sembah catur that an individual should understand that any feelings is given by God and should be accepted whole-heartedly [15].

\subsection{Sembah Rasa}

In Javanese philosophy, mystical peak can only be achieved by sembah rasa which is different from the three kinds of sembah explained above as it is based on anxiety. According to Mangkunegara IV, the author of Serat Wedhatma, this stage of sembah is the devotion towards God by feeling and understanding the life of the universe. If sembah cipta means devotion towards God with soul, sembah rasa emphasizes the use of the core of human spirit [15]. It is the highest and deepest stage of sembah in Kejawen spiritual philosophy. Rasa constitutes the truest awareness located in an individual core and outside the material body. The spiritual journey in this phase 'no longer needs any guidance' or dadine wis tanpa tuduh (Serat Wedhatama gambuh, verse 23) since the individual has already united with God that is manifested in the existence of universe [14].

In this phase, certain religious ritual is no longer considered to be the center of spiritual journey. Instead, all body movements, including footsteps and daily activities, are filled with sumarah feeling which makes an individual certain that his conducts are devoted to attain perfect peace [17]. Clifford Geertz and Niels Mulder admitted the importance of rasa for the Javanese, as by training rasa, human being will be able to bridge the distance with God [18]. Sembah rasa represented in mijil canto verse 97 of $P J$ with the narration of Jaleka's request to a prosecutor to decide her fate following her sexual activities with Yusup. This verse contains the sentence 'which one is right between me (Jaleka) and him (Yusup)' which can be read as the signifier of sembah rasa. It represents human's willingness to present himself to God. The depiction of Jaleka's readiness to face judgment and consequences of her actions is the representation of her union with God.

In the Javanese philosophy, the attainment of perfection is reflected by harmony and union with God [14]. In PJ, the unity of Jaleka with God is attained by sexual activities depicted from the beginning of sembah raga, followed by sembah cipta and sembah jiwa, until the highest phase of sembah rasa. Therefore, the sexual depiction in PJ represented Jaleka's spiritual journey in conducting sembah catur. As noted above, mijil in PJ does not only describe Jaleka's sexual life and can be read as her spiritual journey to attain her perfection as a human being. Analysis on the meaning of sexual depiction in $P J$ shows that the representation of sexuality is the analogy sembah catur as Jaleka's spiritual journey to attain perfection. Human perfection, in Javanese sense, means unity with God. It can be attained by conducting sembah catur.

\section{CONCLUSION}

PJ manuscript describes sexual activities in the form of mijil canto. The canto is understood as the description of the beginning of a sexual intercourse. At the same time, mijil 
can also mean Jaleka's spiritual journey towards perfection. The spiritual journey if represented in PJ by the depiction of Jaleka's sexual activities with Yusup. According to Javanese philosophy, sexual intercourse represents human unity with God by the manifestation of sembah catur (sembah raga, cipta, jiwa, rasa). Therefore, the sexual depiction in PJ provides knowledge about Javanese view on human spiritual journey to attain perfection. The realization of the unity is the purpose of sexual activities conducted by the Javanese.

Acknowledgement. This research is fully supported by Hibah Publikasi Internasional Terindeks Mahasiswa Magister 2019-2020 funded by DRPM Universitas Indonesia No. NKB0998/UN2.R3.1/HKP.05.00/2019.

\section{REFERENCES}

[1] D. B. P. Setiyadi, "Wacana Tembang Macapat Sebagai Pengungkap Sistem Kognisi Dan Kearifan Lokal Etnik Jawa,” Kaji. Linguist. dan Sastra, vol. 22, no. 2, pp. 193-210, 2010.

[2] Poedjosoebroto, Wayang Lambang Ajaran Islam. Jakarta: Pradnya Paramita, 1978.

[3] S. -, "Wawasan Hidup Jawa Dalam Tembang Macapat," Diksi, vol. 13, no. 5, pp. 17-28, 2019.

[4] N. H. Insani, U. N. Semarang, J. Sekaran, G. Pati, K. Semarang, and S. Nitimani, "Sěrat Nitimani : Pendidikan Seks berdasarkan Etika Jawa,” 2018.

[5] Pardi Suratno, "THE CHARACTER OF TEMBANGRARAS AND CHENTINI IN SERAT CENTHINI WRITTEN BY PAKUBUWANA V," DAFIS 1 DHARMA ACARYA Fac. Int. Semin., vol. 3, no. 1, p. 56, 2016.

[6] Nuraningsih, "Nilai Edukasi Metafora Teks-teks Seksual dalam Serat Centhini Karya Pakubuwana V," J. IKADBUDI, vol. Vol 5, No, 2016.

[7] S. Furqon and B. Busro, "Serat Gatholoco: Tubuh Menggugat Agama," Relig. J. Stud. Agama-Agama dan Lintas Budaya, vol. 2, no. 1, p. 15, 2018.

[8] K. Budiman, Jejaring Tanda: Strukturalisme dan Semiotik dalam Kritik Kebudayaan. Magelang, 2004.

[9] A. Todorov, Tzvetan, 1939-2017, T. Bachmid, Talha, T. Djokosujatno, Apsanti, and T. Zaimar, Okke K. S., Tata sastra. Jakarta: Djambatan, 1985.

[10] S. Endraswara, Seksologi Jawa. Jakarta, 2013.

[11] Imam Sutardjo, "Tembang Jawa (Macapat)," Surakarta Jur. Sastra Jawa Fak. Sastra dan Seni Rupa Univ. Sebel. Maret, 2011.

[12] S. Endraswara, Rasa Sejati Misteri Seks Dunia Kejawen. Yogyakarta, 2006.

[13] Siti Mujibatun, "KONSEP SEMBAH DAN BUDI LUHUR DALAM AJARAN MANGKUNAGARA IV DAN RELEVANSINYA DENGAN HADIS NABI," $\mathrm{Al}$ Tahrir, vol. 13, no. 1, pp. 43-60, 2013.

[14] Turita Indah Setyani, "SEMBAH CATUR DALAM SERAT WEDHATAMA MERUPAKAN DASAR PERILAKU BERBANGSA DAN BERNEGARA,” Buku Pros. Konf. Int. Budaya Drh. Ke-2 (KIBD II)Denpasar, 22-23 Februari 2012, vol. 2, no. Kibd Ii, pp. 22-23, 2012.

[15] Purwadi, "NILAI THEOLOGIS DALAM SERAT WEDHATAMA," DIKSI, vol. Vol 14, No, pp. 81-88, 2017.

[16] A. Jatmiko, Tafsiran Ajaran Serat Wedhatama. Yogyakarta: Pura Pustaka, 2012.

[17] dan H. Daruni, Endang., Suhartoyo, Asdi., Laporan. Penelitian Jaran Etik dalam Serat 
Wedhatama dan Relevansinya dengan Etika Pancasila. Yogyakarta, 1986.

[18] Dr. Paul Stange, POLITIK PERHATIAN Rasa dalam Kebudayaan Jawa. Yogyakarta: LKIS Yogyakarta, 2007. 